$2021 \uparrow$ Volume $24 \uparrow$ Issue $3 \uparrow 5-28$

DOI: $10.33223 / \mathrm{epj} / 141095$

Yevheniia Sribna ${ }^{1}$, Viktor Koval ${ }^{2}$, Piotr OlCZAK ${ }^{3}$, Dmytro BizonYch $^{4}$, Dominika Matuszewska ${ }^{5}$, Oleksandr ShTYRov ${ }^{6}$

\title{
Forecasting solar generation in energy systems to accelerate the implementation of sustainable economic development
}

ABSTRACT: The analysis and assessment of the development of solar energy were carried out and it was noted that the production of solar electricity in the world has increased by more than $15 \%$ over the last year. In 2020 there are more than 37 countries with a total photovoltaic capacity of more than one $\mathrm{GW}$, and the share of solar energy in total world electricity production was $8.15 \%$. In the regional context, the largest production of electricity by solar energy sources is in Asia (at the expense of India and China) and North America (USA). The study assesses the main factors in the

\footnotetext{
$\square$ Corresponding Author: Piotr Olczak; e-mail: olczak@min-pan.krakow.p1

1 National University of Water Management and Environmental Engineering, Rivne, Ukraine; ORCID iD: 0000-0002-6676-0606; e-mail: e.v.sribna@nuwm.edu.ua

2 National Academy of Sciences of Ukraine, Kyiv, Ukraine; ORCID iD: 0000-0003-2562-4373; e-mail: victorkoval@ukr.net

3 Mineral and Energy Economy Research Institute, Polish Academy of Sciences, Kraków, Poland; ORCID iD: 0000-0002-4926-0845; e-mail: olczak@min-pan.krakow.pl

${ }^{4}$ Etalontechservice LLC, Kharkiv, Ukraine; e-mail: bizonych23@ukr.net

5 AGH University of Science and Technology, Kraków, Poland; ORCID iD: 0000-0002-8899-012X; e-mail: dommat@agh.edu.pl

${ }^{6}$ Petro Mohyla Black Sea National University, Mykolaiv, Ukraine; e-mail: bratislava@ukr.net
}

(C) 2021. The Author(s). This is an open-access article distributed under the terms of the Creative Commons Attribution-ShareAlike International License (CC BY-SA 4.0, http://creativecommons.org/licenses/by-sa/4.0/), which permits use, distribution, and reproduction in any medium, provided that the Article is properly cited. 
development of solar energy from the standpoint of environmental friendliness and stability of the electricity supply. The problem of the utilization of solar station equipment in the EU and the US is considered. According to the IPCC, IEA, Solar Power Europe, forecasting the development of solar energy in the world is considered. It is proved that the main factor in assessing the economic efficiency of solar energy production is a regional feature due to natural and climatic conditions (intensity of solar radiation). The use of solar generation is auxiliary for the operation of modern electrical networks as long as the efficiency of photovoltaic cells increases by at least $60-65 \%$. Marginal costs of solar energy are minimal in those countries where active state support is provided. The competitiveness of solar energy is relatively low. However, from the standpoint of replacing energy fuel at a cost of USD 10 per 1 Gcal of solar energy saves 10-20 million tons of conventional fuel. Industrial production of solar electricity at modern solar power plants forms a price at the level of USD 250-450 for $1 \mathrm{MWh}$.

KEYWORDS: solar energy, production and consumption of electricity, "green" tariff, disposal of solar panels

\section{Introduction}

The development of renewable energy and the accelerated pace of innovative change in the context of digitalization expand the capabilities of the energy sector and increase the efficiency of this sector of the economy. The UN Sustainable Development Goals have identified global concepts, international commitments and national priorities for the development of clean energy sources. However, renewable energy sources remain a problem for power supply systems, as they require additional costs for storage, balancing and transmission of electricity and, in general, require increased flexibility. The technological improvement of solar energy takes place in various ways: from the production of panels and components to the technologies of connection and distribution (use of existing transmission lines), as well as the disposal of solar panels and their reuse (Żelazna et al. 2020).

At the same time, the development of the global economy and the slow decline in energy intensity are increasing the demand for solar electricity. This "new" energy is already being used in the heating and transport systems. For example, charging cars from solar panels, charging cars at stations when electricity is accumulated from solar energy and as transport companies in the role of economic entities. Recently, V2G technology has been developed, which allows the use of electric vehicle energy in the grid. In addition, the introduction of the "green" tariff has led to a distortion in the priority of the development of all energy, and investment capital has focused on short-term projects in renewable energy. Additional costs for the protection and failure prevention system of such stations remain quite meager (Majchrzak et al. 2021). The very impact of these stations in periods of dynamic change of rapid climate change, and especially anomalies, indicate the imperfection of both the stations themselves and the entire energy system (Wróblewski et al. 2021). 
The purpose of the study is to assess the development of global solar energy and specify the problems of its use, which requires the assessment of trends and forecasts of solar energy development; analyses of the pricing system in solar energy; description of the environmental and social consequences of the operation of solar power plants.

The novelty of the study lies in forecasting of the authors scenario of solar energy development until 2030 implemented through technologies of digitalization of energy management and innovative implementation of technological changes in the production of equipment and elements of solar power plants. Such changes in general form in the economy growth of 10 to $50 \%$ depending on the industry. For energy, this figure will be $15 \%$. This is due to the conversion of renewable energy into digital mode, while not taking the innovative breakthroughs in obtaining additional capacity for modern production of solar panels into account.

Research consists of 5 Sections. In Section 2, the literature review about solar energy is described, forecasting methods for solar generation are summarized in Section 3, the results are discussed in Section 4, and finally conclusions are provided in Section 5.

\section{Literature review}

The Paris Climate Summit was preceded by a September meeting of representatives of UN member states, which resulted in the project entitled "Transforming Our World: An Agenda for Sustainable Development until 2030" (Transforming... 2015). It identifies 17 global goals of sustainable development, the achievement of which will provide an opportunity to at least health, quality education, gender equality, clean water and sanitation, renewable energy, decent work and economic growth, innovation and infrastructure, reducing inequality, sustainable development of cities and communities, responsible consumption, climate control, life under water and on land, peace and justice, partnership for goals. Many scientists point out that the development of renewable energy is a priority, as it is a prerequisite for solving all other problems partially address the most pressing issues facing humanity today. These include tackling poverty, hunger, improving, specified in the implementation of the Sustainable Development Strategy (Ciuła et al. 2019; Gielen et al. 2019; Hák et al. 2016; Hutsaliuk et al. 2020; Owusu and Asumadu-Sarkodie 2016). The use of renewable energy sources contributes to the sustainable development of cities, which thanks to solar, wind, biogas plants, small hydropower plants can provide themselves with electricity, while reducing their costs and resource dependence (Kumar 2020; Spillias et al. 2020; Tsimoshynska et al. 2021). The population can generate electricity independently and control its distribution, while also minimizing losses during long-distance transmission (Mulatu 2017). This, in turn, reduces the burden on nature and makes it possible to talk about economic growth, which today is constrained by our usual extensive traditional energy (Koval et al. 2019a). Every year, "green" energy becomes more accessible, new production technologies are invented, which 
undoubtedly contributes to the development of innovation and improvement of infrastructure (Mikhno et al. 2021).

Solar energy is one of the most promising and dynamic renewable energy sources. Scientists study the development of solar energy. Particularly, Thamyres Machado David and el. (David et al. 2020) analyzed scientific publications in the field of solar energy research for the period 2000-2019. Based on the analysis authors suggested ten topics of future research tendencies (David et al. 2020) and viewed the literature on big data models for solar photovoltaic production forecasts (Alawaji 2001).

Kannan Kaliappan et al. (Kaliappan et al. 2019) analyze solar energy technologies in the world's leading countries. In particular, the analysis of such countries as China, the US, South Korea, and India is carried out. The authors conclude that investors or consumers should be provided with subsidiaries to simplify the construction of a solar power plant and purchase solar panels. Nathan S. Lewis offers research on opportunities to improve the use of solar energy and gives a chronology of the total installed cost for some large solar thermal projects (Lewis 2016).

Jonathan Hayes points to the need for fundamental concepts of solar energy and the importance of its potential application due to the future solution of the energy crisis (Hayes 2012).

Punniamoorthy Ravirajan consider that in order to develop solar electricity in the country, a competent workforce that can solve complex technological problems related to solar energy (from production to installation, repair and maintenance) must be a prerequisite (Ravirajan 2017).

Can Wan et al. (Wan et al. 2015) present scientific work, which studies the development and forecast of solar energy. The paper describes the advantages and disadvantages of four models of solar energy forecasting, namely statistical models, AI-based models, physical models and hybrid models (Wan et al. 2015).

Maroua Haddad et al. (Haddad et al. 2019) present a comparison among four distinct solar radiations. According to their estimates, it is optimal to use the SARIMA model due to seasonal distribution to predict solar radiation (Haddad et al. 2019). De Gruyter believes that it is much more convenient and accurate to predict using GA compared to the statistical method of analysis (Pattanaik et al. 2020).

Shahsavari Amir and Akbari Morteza extensively study the problems of solar energy, in particular, to consider the sources of energy emissions (Shahsavari and Akbari 2018). Solar energy can be used in underdeveloped countries and in areas that are remote from centralized electricity grids. In addition, PV is convenient to use to reduce the demand for fossil fuels and associated emissions (Kaczmarzewski et al. 2019; Mirowski and Sornek 2015; Olczak et al. 2021).

Thus, the role and significance of solar energy in modern conditions are thoroughly and extensively explained in scientific research. The authors analyze the development of solar energy in both developed and developing countries. However, forecasting the use of solar renewable energy sources for sustainable economic development requires further research and evaluation of their practical application. 


\section{Solar forecasting methods}

To review the problem of forecasting solar generation a range of various systematic methods and approaches were used, which are in line with modern research within the framework of logical, comparative, statistical analysis, the analysis of dynamics, graphic, pricing and financial analysis methods, the interpretation of information.

The study examines methods, examples and evaluations of the effectiveness of various solar energy, various options for pricing and government policy in this area. System analyses helped us to identify reasonable measures of existing systems of solar energy or by introducing new technologies including the cost-effectiveness and practicability.

System analyses in our research are used for:

1. Analysis of the installed capacity of solar energy in the world.

2. Possibilities of using solar energy in the regional context.

3. Development of solar energy concepts.

We conducted a literature review of current processes in solar in the field of solar energy. This knowledge assisted us a comparative analysis of these processes in the regional context. The development of solar energy is extremely uneven, so the main emphasis is on the main centers of its development - the North America, Europe and Asia.

With the forecasting method, we used historical data as inputs to make informed estimates that are predictive in determining the direction of future trends of solar energy in the world. In the field of solar energy, the scenario of its development assumes the maximum use of economic incentives, legislative and regulatory and organizational measures to ensure the profitability of the electric power industry, the implementation of a rational tariff policy and the intensification of energy conservation in the coming years.

\section{Results}

\subsection{Trends in the development of solar energy}

Solar energy is one of the main types of renewable energy sources, as it uses the primary and permanent source of energy - the sun. However, its industrial use began only in the early 1970s, in response to the energy crisis. In 1980, the Japanese government formed the Sunlight Program, which funded USD 3.5 billion by 2000 and commissioned photovoltaic plants with a capacity of $1 \mathrm{MW}$ and $100 \mathrm{MW}$. In 2015 two floating solar power plants on the surface of Nishihira and Higashihira Ponds, with a total capacity of $3300 \mathrm{MWh}$, which provided electricity to 920 residential buildings (Ohta 2020). 
In the United States, solar energy began to develop in 1971, during the 5 years of the Solar Roofs program; USD 1 billion as allocated for its development. This ensured that by the end of $1976,25 \%$ of electricity to the household sector consumption for heating and cooling was transferred to solar generation. At the end of 1976, 30 buildings and 4 schools were fully operational due to solar energy. US researchers have indicated that solar energy will be fully competitive provided that the cost of USD 10 will provide $0.116 \mathrm{Wh}$, other words will save from 10 to 20 million tons of conventional fuel (Solar... 2021). Since 2009, China has formed and is implementing the Golden Sun program to implement the latest solar energy projects in all provinces of the country. Since 2012, the solar parks have been introduced (Wang et al. 2017).

Further development of solar energy was a consequence of the implementation of the Kyoto protocols to reduce carbon dioxide emissions. External factors (fuel crisis, Kyoto Protocol) are macroeconomic factors in the rapid development of solar energy. In addition, the investment component of this energy is quite low:

$\checkmark$ the equipment is not demanding and requires minimal maintenance,

४ the equipment provides full automation of the whole process,

$\checkmark$ one-time implementation, payback period of 20-30 years (difference in station type, climate),

$\downarrow$ both the autonomous station and separate elements and units of the base power generating station can be used.

The main disadvantages of solar electricity are:

- weather and climatic conditions (requires a high level of intense sunlight),

$\downarrow$ high cost of modern electricity. For example, in Japan, the cost of a power plant is 1 million JPY per $1 \mathrm{~kW}$,

$\downarrow$ the cost of production remains expensive - tens of times higher than nuclear energy,

$\checkmark$ the level of efficiency of solar power plants is from $15-20 \%$.

In modern conditions, solar power plants can be in the form of:

$\downarrow$ photovoltaic (PV) systems that use solar panels on roofs or on terrestrial solar trusses, converting sunlight directly into electricity,

४ concentrated solar power plants (CSPs, also known as "concentrated solar thermal energy"), which use solar thermal energy to produce steam, which is then converted into electricity by a turbine (Viebahn et al. 2011; Wang et al. 2019).

Modern uses of solar energy are depicted on Figure 1.

Thus, according to Ember electricity consumption in 2019 increased by $357 \mathrm{TWh} / \mathrm{year}$ and during the 2010-2019 biennium. This growth amounted to an average of $643 \mathrm{TWh} /$ year (Solar... 2021). During the 18 years since 2000 world energy production increased by $3 \%$ per year. In 2019 , the growth was only $1 \%$. This is due to changes in climatic conditions, as winters have become milder and economic growth has slowed. At the same time, coal-based electricity production in 2019 decreased by $259 \mathrm{TWh}$, i.e., by $3 \%$. During this period, the growth of electricity production based on solar energy was about $15 \%$, and the share in total world electricity production was $8.15 \%$ (Alster et al. 2021). In the regional context, the largest production of electricity by solar energy sources is in Asia (at the expense of India and China) and North America (USA) (Table 1). 


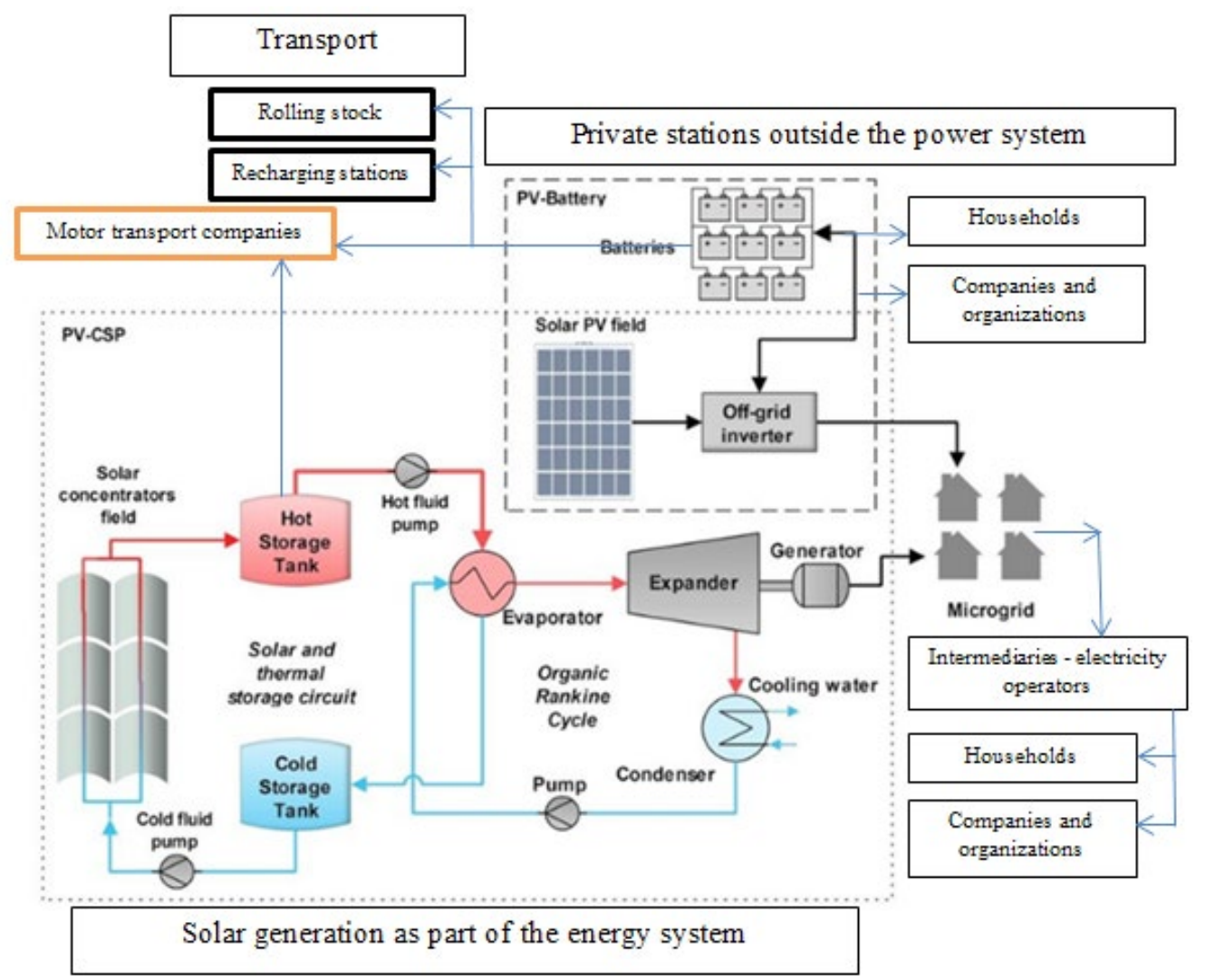

Fig. 1. The PV-CSP system and the PV-Battery system (Alster et al. 2021)

Rys. 1. PV-CSP i PV-Battery system

While in 2010 there were 7 countries with an installed solar energy capacity of more than $1 \mathrm{GW}$, in 2020 there are more than 37 countries with a total photovoltaic capacity of more than $1 \mathrm{GW}$. In the regional context, the largest installed capacity of solar energy is located in Asia, as in early 2020, China leads in the production of solar energy with a capacity of $208 \mathrm{GW}$, which is one third of the total installed solar capacity.

In 2019, $16.7 \mathrm{GW}$ of solar power plants were put into operation in European countries, which is $104 \%$ more than in 2018. The leader of the European "solar" market is Spain, where in 2019 the capacity of solar energy was $4.7 \mathrm{GW}$. The second position is occupied by Germany (4 GW). In the Netherlands, $2.5 \mathrm{GW}$ of solar power, in France - $1.1 \mathrm{GW}$ (Alster et al. 2021).

Thus, in the world there is increasing production of electric current from solar power, solar station and they undergo significant changes. Accordingly, solar energy is divided into two sectors - the sector of solar stations based on the photoelectric effect (Solar photovoltaic) and based on the heat of the sun, which leads to the action of a heat engine (Concentrated solar power). 


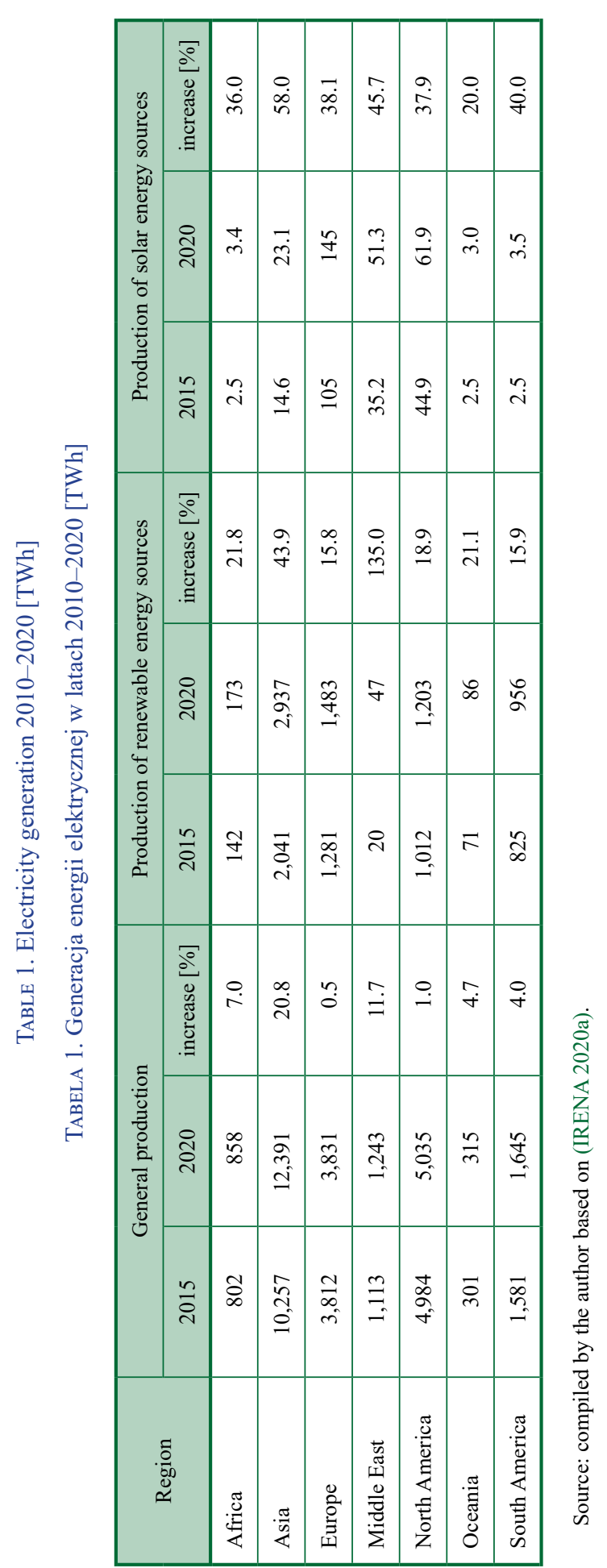




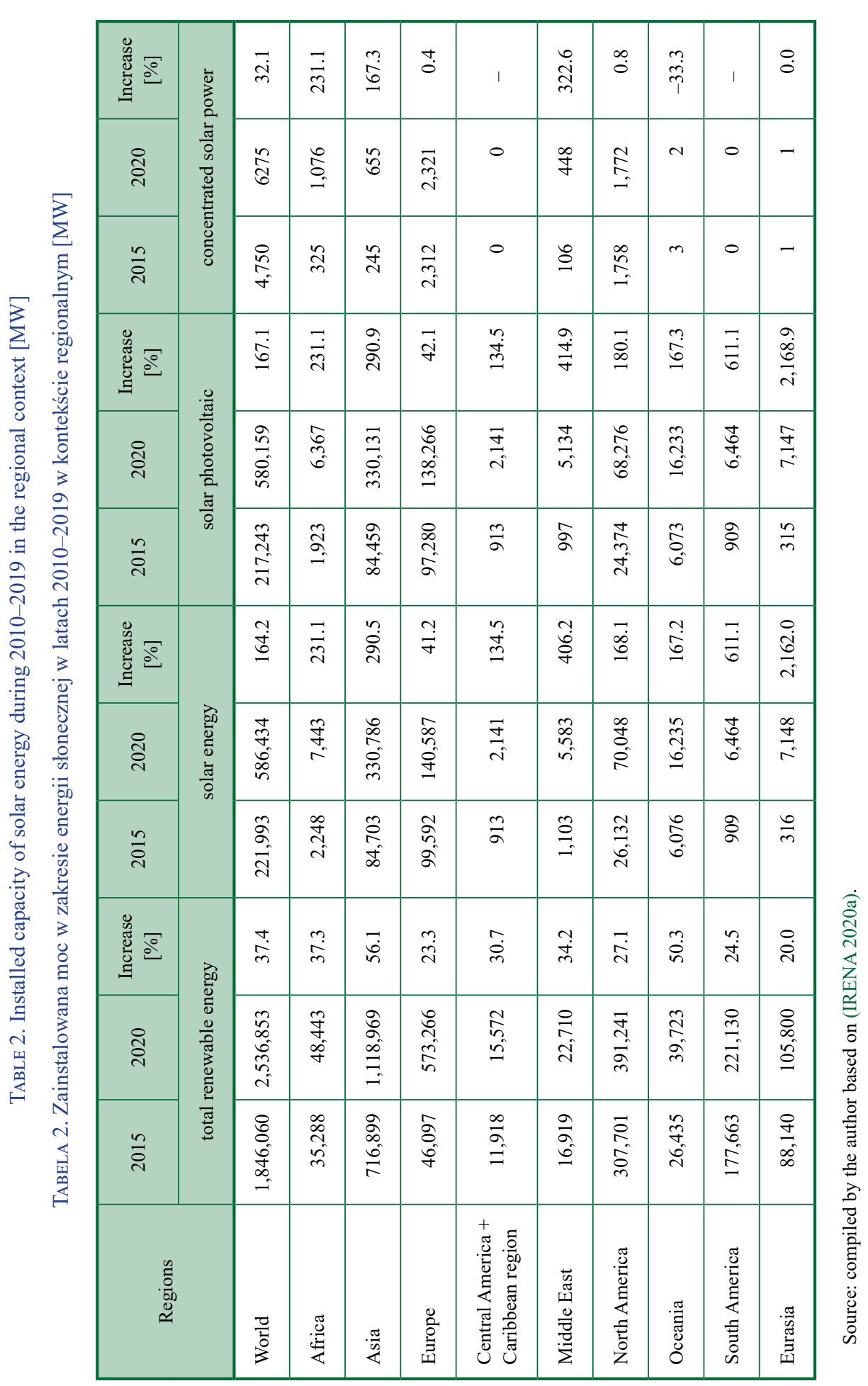


The regions in which solar energy began to develop the most were the Middle East, South and North America, as well as Africa (Viebahn et al. 2011).

\subsection{Forecasting of solar energy development}

Addressing global environmental issues, in particular the Paris Agreement under the UN Framework Convention on Climate Change requires an increase in the share of renewable energy of at least $15 \%$ annually by 2030 . In addition, two basic forecasts of renewable energy were developed: IPCC and IEA (Fig. 2). There is no significant difference in these forecasts; they are focused on the requirements of the Paris Agreement. According to the conservative scenario, in 2021 the solar generation capacity is projected to increase by $22 \mathrm{GW}$, in 2022 - by $24.3 \mathrm{GW}$, and in 2023 - by $26.8 \mathrm{GW}$.

In this perspective, an interactive model of the global energy system has already been developed, which will work exclusively on renewable energy sources. This is a long-term forecast of reformatting of all energy in order to cover the need for electricity every hour of the year.

According to such calculations, with the optimal combination of production generation and storage infrastructure and network economy will determine the cost of one megawatt-hour of electricity in the range of EUR 55-70 in most regions of the world. In addition, such a future system will allow working stably and regularly, to cover the instability of solar and wind power

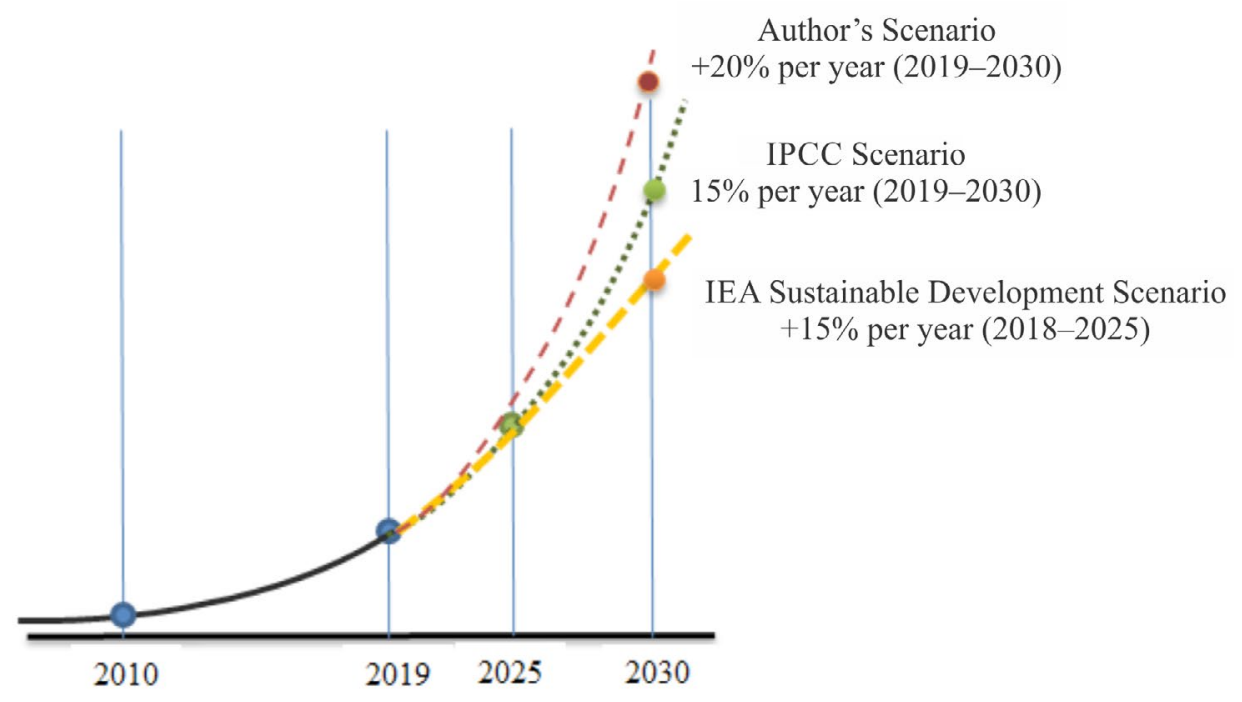

Fig. 2. Forecasting scenario for the growth of solar generation capacity by 2030 (Renewable energy 2021; The IPCC's reports 2021)

Rys. 2. Scenariusze prognostyczne dla wzrostu mocy instalacji słonecznych 
plants and to fully replace thermal power plants and nuclear power plants to maintain the "base capacity" of the grid.

The European Solar Energy Association Solar Power Europe has predicted the development of solar energy in the world by 2024, including such regions as North America, South America, the Asia-Pacific region, Asia, Europe. The Global Market Outlook 2020-2024 report proposes 3 scenarios (Low Scenario, High Scenario, Medium Scenario) (Fig. 3) (Total installed... 2020). By the end of 2024, the installed capacity of solar energy in the world will reach $1448 \mathrm{GW}$ (EU Market Outlook... 2020). In addition, Spain, Germany, Denmark are leaders in the incidence of installed PV capacity.

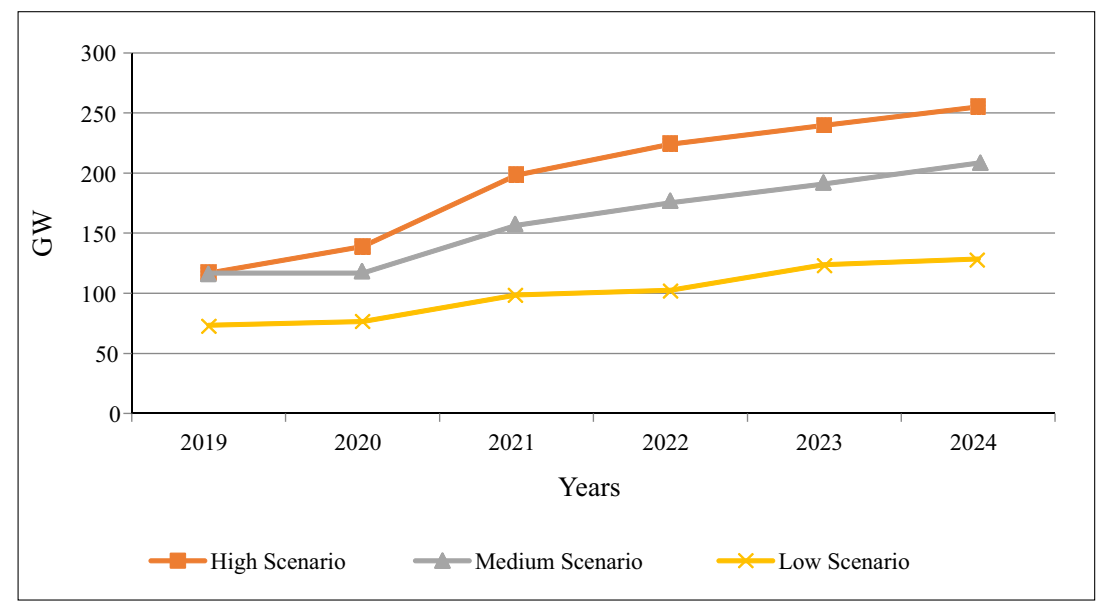

Fig. 3. Forecasting scenario of solar generation capacity growth until 2024 (BNEF... 2021)

Rys. 3. Scenariusze prognostyczne wzrostu mocy wytwórczych energii słonecznej do $2024 \mathrm{r}$.

Assessment of the economic efficiency of solar energy production takes various factors into account: the cost of labor materials and land, the possibility of attracting investments. However, the main factor remains a regional feature due to natural and climatic conditions (intensity of solar radiation). The combination of these factors and the system of state support and determines the limits of the cost of electricity production (Fig. 4) for individual countries. In countries where there is active state support for the development of solar energy, the limits on solar energy expenditure are minimal (Japan, Germany, Belgium, Bulgaria and Spain). In addition, the cost of a solar power plant is reduced by the intensity of solar radiation. Therefore, the cost of solar stations in China and India is many times lower than in European countries.

Unequivocally, the high growth rates of electricity production are due to significant government support. It is through government support that solar energy remains attractive when economic efficiency is much worse than when using fossil fuels.

The rapid increase in the use of new solar power plants in the electricity sector poses additional challenges to the entire energy sector, related to the need for capacity redundancy and storage 


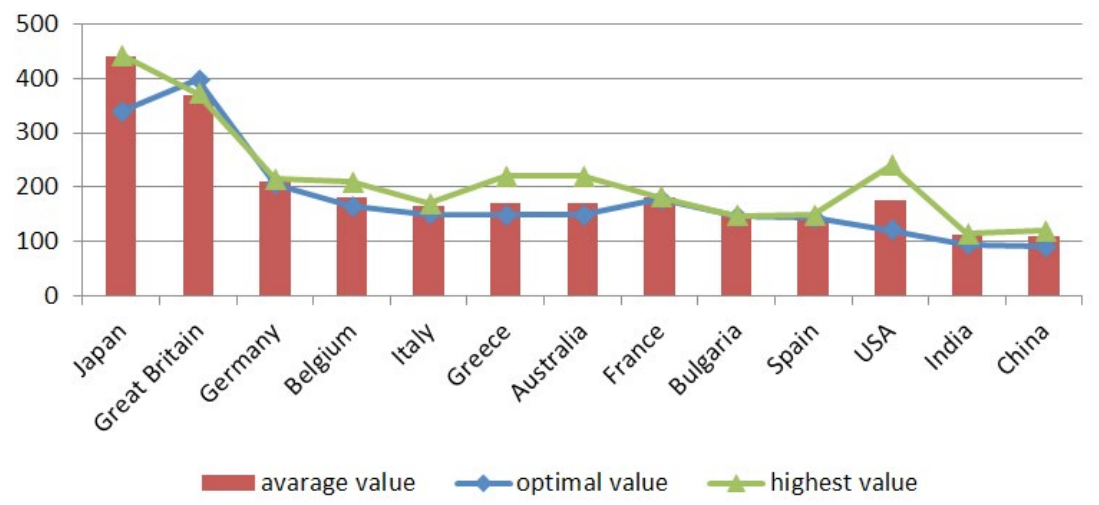

Fig. 4. Specific discounted costs of electricity production based on solar installations [USD/MWh] (BNEF 2021)

Rys. 4. Określone zdyskontowane koszty produkcji energii elektrycznej w instalacjach fotowoltaicznych

to ensure the flexibility of the power system. In addition to the daily irregularities of electricity generation at solar energy facilities, the seasonal component, which is manifested through changes in the intensity of solar radiation at different times of the year, should be noted. Because of this, the average monthly capacity utilization may differ several times. In fact, this establishes an additional hidden investment margin for the energy sector, which is often not taken into account when directly comparing the cost of producing electricity from different sources.

\subsection{Climatic problems in the operation of renewable energy stations}

However, the reality of renewable and traditional energy is different. For example, the climate-friendly American state of Texas in mid-February 2021 fell into an energy crisis. The territory of this state is quite favorable for solar energy, because the air temperature did not fall below zero degrees. The main dangers for Texas were tornadoes in the central part of the state and periodic tropical cyclones. The power system is represented by 12 CHPs with a total capacity of 45.8 GW, one nuclear power plant (South Texas Nuclear Generating Station) with a total capacity of 2,708 MW, has the largest share of wind production $10 \%$ of the state generation, which is the largest the number of stations in the United States with a total capacity of over 22,500 MW (ELECTRICITY 2021). Solar energy is represented by the Roadrunner power plant in Upton County, which has not yet been completed, but already generates 497 MW. These stations are connected to one internal power grid, which is completely independent of other states.

The winter snowstorm and low temperatures in the state led to an increased demand for electricity. However, the solar stations were covered with snow, and most wind farms were shut down due to lack of insulation mechanisms. In addition, the Texas power grid has no backup 
power supply. Accordingly, the sharp increase in the use of electricity has led to the need to manually adjust the balance in the power system, which ultimately led to the fact that in 7 days more than a third of the generating capacity of the state was disconnected from the grid. The electricity generating capacity was stopped due to the possibility of freezing of mechanisms and installations and power outage for gas injection at CHP and water at NPPs. As a result, wholesale electricity prices in Texas rose by USD 10,000 per MWh, when the average wholesale price was USD 28 per MWh. Residents began receiving payments of USD 2,739 in just 20 days in February against the average winter months of USD 130 . Therefore, regional regulation of electricity prices began and the marginal price was set at USD 9,000 per MWh, and average prices became USD 8,800 per MWh. Preliminary losses due to the failure of the Texas power system are estimated at USD 50 billion (Najmabadi 2021).

Another case in 2020 in California - record summer temperatures led to an increase in demand for electricity for air conditioners, but the failure of wind and solar power plants did not meet the needs. In Germany, snowfall in 2021 halted all solar generation, and 30,000 wind turbines were shut down, reducing the share of renewable energy by $0-3 \%$.

Thus, modern solar energy is very vulnerable to sudden natural disasters. And this puts forward the need for its mode of operation in combination with traditional energy. As an independent energy sector, solar generation is not the dominant condition in ensuring the energy security of a region or country in climatic zones that are subject to abrupt changes in long-term weather anomalies. It should be noted that such anomalies are manifested in different and different solar-active areas of the world. Science at this time is unlikely to predict and warn. Therefore, solar energy will remain a complementary element to traditional energy.

\subsection{Problems of decommissioning and utilization of solar power plant equipment}

A separate problem of solar energy, which is insufficiently analyzed in scientific publications and economically invaluable - is the problem of recycling solar panels. According to world forecasts, by 2030 the world will need to produce up to 700,000 tons of single-crystal silicon per year to meet solar energy equipment. The work of IRENA and IEA "End-of-Life Management: Solar Photovoltaic Panels" (Weckend et al. 2016) remains relevant, in which this problem was considered and brought to the international level. In particular, it was indicated that the total accumulation will be 1.7-8 million tons of solar panel waste by 2030. In the valuation, only one material is worth USD 450 million. In the EU, this problem is taken under separate control and the Waste Electrical and Electronic Equipment Directive has been developed, which requires the mandatory reuse of $65-70 \%$ by weight of materials.

In the vast majority of other countries, solar energy waste is industrial waste. However, NSF 457-2019 "Sustainability Leadership Standard in the Context of Solar Panels and Solar Inverters" (Sustainability... 2019) already includes this in the area of responsibility in addition to solar 
panel manufacturers and buyers, as well as equipment extensions, in addition to solar panels included inverters and solar panels. Standards EN50625-2-4 and TS50625-3-5 relate exclusively to the collection and recycling of solar panels, which set out various requirements for the prevention of pollution and emissions and increase the proportion of renewable materials and deep processing operations. In the modern condition there are thick processing (when plastic is burned and glass, aluminum, and copper are mined) and thin processing (deposition of layers of photovoltaic material on a glass, plastic or metal substrate) PV-modules.

As for the cost-effectiveness of solar power disposal, it is still clear that the cost of scrap (ferrous metal and copper) exceeds the cost of decommissioning the solar power plant. With the full cycle of decommissioning from solar stations, net income will be USD $0.01-0.02$ per 1 watt and this without taking into account the value of the land. In general, it is noted that achieving a break-even level is possible with annual processing volumes of 20 thousand tons.

Most solar waste is recycled at e-waste and laminated glass plants. However, this activity is also in the interests of private international business. Thus, First Solar has been implementing an international project for the collection and processing of its own thin-film CdTe panels since 2005, and in 2018 switched to zero liquid wastewater discharge technology. However, the volume of recycling is quite small - only $10 \%$ of the dismantled panels and others are simply dumped and partially exported to third countries. The cost of primary processing of solar panels ranges from USD 12 to 25 , and the cost of removal to the landfill is not more than one dollar (Utility-Scale 2021).

Since 2009, the European Pattern Recognition (EPR) project "PV Cycle" (European... 2020) for the processing of solar panels has been operating in Europe, and waste collection centers have been established. Since 2014, all producers of solar energy infrastructure have become participants in this project.

Thus, the real economic feasibility of recycling solar panels is quite unprofitable, so most of the panels end up in landfills after primary processing. This is due to the problem of economic development of different countries. So some countries buy used panels for further use, and in others they are taken to a dump.

Innovative developments in the field of recycling of used solar panels are imperfect and are in the initial phase of their development. Modern processing does not influence the formation of the cost of consumption of $1 \mathrm{~kW}$ of energy. In technological terms, such processes are not processed, and therefore do not directly affect the production of solar electricity.

\subsection{Pricing in solar energy production}

Serial production of solar power plant components and the interest of international corporations in this business have led to a decrease in the cost of production of $1 \mathrm{MWh}$ of solar electricity. If in 2010 the cost of solar PV panel was USD 4394 per kW, then in 2017 the price dropped to USD 1388. And currently this cost is USD 35-50 per MWh. However, the industrial use of 
solar energy forms a price of USD 250-450 for $1 \mathrm{MW}$. Theoretical studies on the possibility of solar stations as a single international network indicate the possibility of reducing this price to EUR 55-70 (Household... 2021).

The weighted average cost of electricity from large solar panels in different countries decreased depending on the increase in capacity and fell from $55 \%$ to $80 \%$ (Fig. 5).

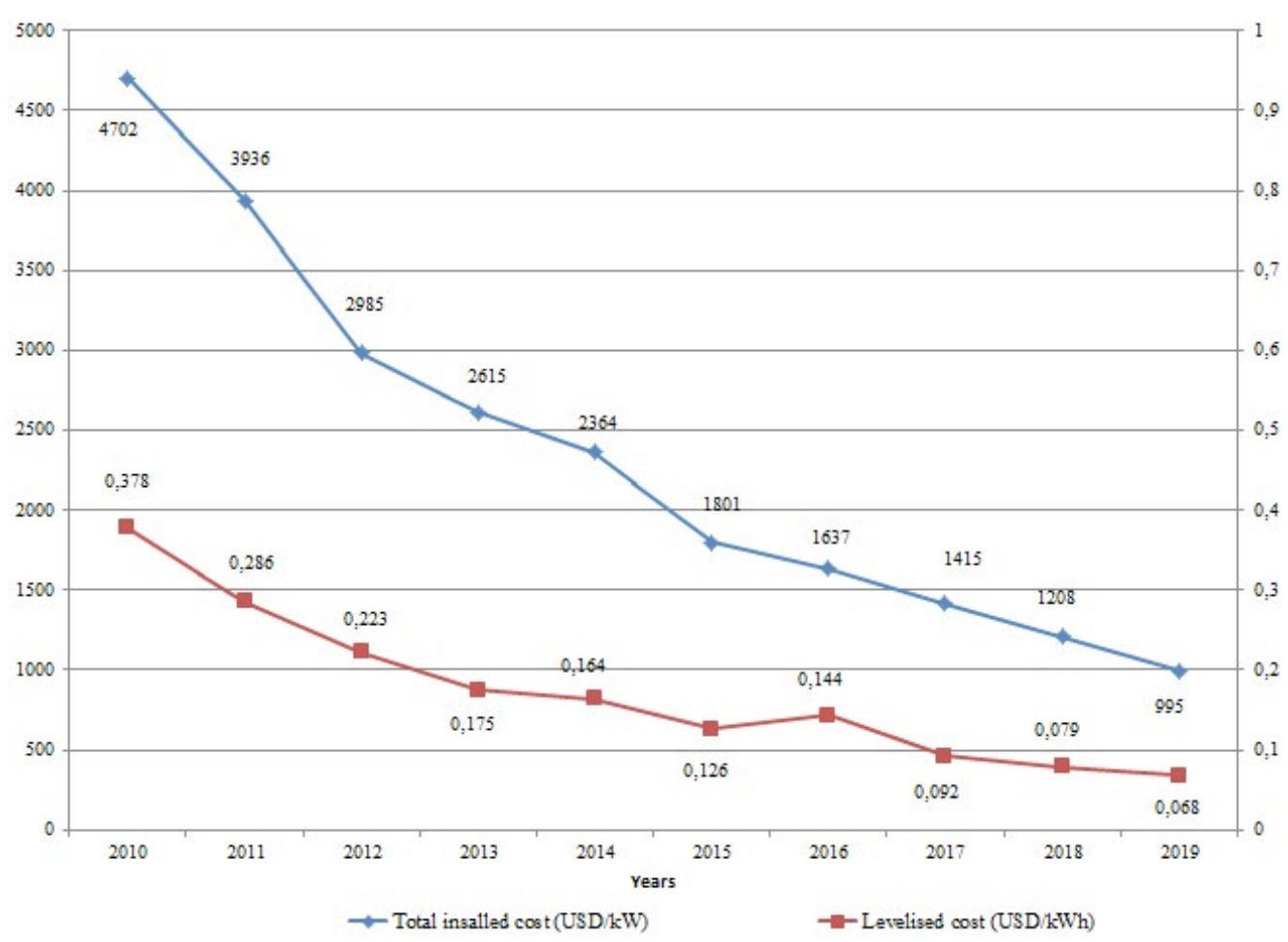

Fig. 5. Global weighted average total installed costs and LCOE for solar PV (2010-2019) (IRENA 2020b)

Rys. 5. Globalna średnia ważona całkowitych kosztów instalacji i LCOE dla fotowoltaiki

Power Purchase Agreement (PPA) in the last year indicates the price of solar electricity could average USD $0.039 / \mathrm{kWh}$. This means that compared to last year there is a drop of $42 \%$ and corresponds to the fifth cost of the cheapest electricity on fossil fuels remaining in coal-fired power plants.

Solar photovoltaic auction figures in countries such as Ethiopia, Peru, Chile, Saudi Arabia, Mexico, and the UAE confirm that the price is USD $0.03 \mathrm{US} / \mathrm{kWh}$ is possible in 2021 (IRENA 2020b).

In India, the average weighted total estimated cost in 2019 was USD $618 / \mathrm{kW}$, due to the growing number of competitive projects, which is five times lower than in China. 
However, for the period being, competitive cost structures are not limited to established markets. For example, in countries such as Ukraine and Vietnam, photovoltaic energy is a profitable choice of technology. Thus, in 2019, the weighted average total installed cost was USD 874/kW, and in Vietnam, this figure was USD 1054/kW. These values are increasingly on par - and sometimes even cheaper than the averages in a number of cost-mature markets.

For some countries, the price component is determined by the legislative field. Thus, the investment component of Ukrainian entrepreneurship SES is characterized by the fact that at the end of 2019, the station with a capacity of $30 \mathrm{~kW}$ with installation, commissioning and commissioning cost USD 20 thousand. In a year, such a station, taking into account its own electricity consumption, will generate $30,000 \mathrm{kWh}$. Given that the cost of $1 \mathrm{~kW}-$ EUR 0.16 , for the year such a station provided income at the level of EUR 4,800 or USD 5,520. From this income tax in the amount of $19.5 \%$, this is USD 1,104 . Therefore, net income is USD 4,416 . In fact, in 5 years the cost of such a station is fully recouped. However, in 2004 the National Commission for State Regulation of Energy and Public Utilities issued a resolution setting the value of the green tariff at EUR 0.40. The cost of installation and installation of such a station cost USD 45 thousand.

In 2015, the hryvnia (UAH) was devalued from 8 to 20 , and in the same year the National Commission for State Regulation of Energy and Public Utilities introduced a new green tariff of EUR 0.18. Therefore, an alternative use of investment: with investments of USD 45 thousand, income in the amount of USD 25 thousand was received assuming that the tariff was reduced and the UAH devalued. Net income would be USD 15 thousand. The cost of such a second-hand station was USD 15 thousand in 2019 (and a new one is USD 20 thousand). This indicates that the investment in the amount of USD 45 thousand decreased by USD 15 thousand. Therefore, an average of USD 400/month would be economically feasible to use for personal consumption. Therefore, for 5 years USD 20 thousand would be spent. Accordingly, the net balance of fixed capital (45-20) would be USD 25 thousand. In 2019, with its own consumption, it would be possible to purchase a new solar station for the same capacity and the same station with the intention that it can generate revenue.

It should be noted that the cost of selling $1 \mathrm{~kW}$ of solar power is additionally tied to the cost of electricity in the energy market. Therefore, it should be borne in mind that with the devaluation of the UAH there will be a reduction in the green tariff (analogy with 2014).

In 2020, the law "On Amendments to Certain Laws of Ukraine on Improving the Conditions for Promoting Electricity Generation from Renewable Energy Sources" (Verkhovna Rada of Ukraine 2020) was adopted, which states that solar stations mounted on the ground are excluded from payment at the green rate (stations with a capacity of $30 \mathrm{~kW}$ on the roof are not technically installed, because 1 sq. m. produces 150 watts of power).

This situation has developed due to the impossibility of leakage of revenues from generating companies to the market of energy generation, which is formed by nuclear, thermal, hydro and solar energy. The share of solar energy in $1 \mathrm{~kW}$ is a minimum of $1.5 \%$. Solar electricity is purchased in the amount of USD 0.2, and its wholesale price is USD 0.08. These stations take part of the profits from the owner of thermal power plants (DTEK). 
Ukrenergo as a supplier of electricity to end users receives a guaranteed tariff for the supply of $1 \mathrm{~kW}$ of electricity from SES 4.2 UAH. At the same time, consumers pay an average of UAH 2.6. Then this transfer tariff covers the difference between the purchase of UAH 4.2 and the sale difference of UAH 2.6. (sales of electricity per $1 \mathrm{~kW}$ for TPPs is UAH 1.6, and for NPPs - UAH 0.54). In 2020, as many solar power plants were put into operation in Ukraine as in 10 years. This means that there is not enough money to cover the difference between the generating SES and the consumers. Therefore, the National Commission for State Regulation of Energy and Public Utilities is raising the tariff for electricity transmission. When introducing auctions for the sale of electricity under the new legislation, the owners of solar stations are obliged to carry out guaranteed generation (a clear schedule, which marks the hourly transfer of energy to Ukrenergo and then pay a green tariff of EUR 0.18). Accordingly, there are abuses. After all, a solar power plant is not able to guarantee a constant supply of electricity through the technological process in contrast to conventional power plants. As a result, individual solar stations are forced to form groups in order to ensure a guaranteed supply of electricity. This automatically leads to the formation of a participant in the energy market, which will be subject to fines for non-compliance with the guaranteed supply of electricity, which will be paid from the green tariff of EUR 0.18. Therefore, in the energy market, these owners of solar power plants become responsible for the imbalances of these power generation stations. For those who agree to such a market restructuring, imbalance rates are $20 \%$ per year. From 2021, fines will increase by $20 \%$ annually. And at the end of 2025 the growth will be $100 \%$.

Those stations that do not become market participants (remain at a rate of EUR 0.18), from 2023 will be forced to pay a fine of $100 \%$. The specifics of the regulation of the green tariff in Ukraine are that the tariff is set for 10 years without changes, in fact, for stations that are introduced by 2020, a single tariff is guaranteed. In 2019, DTEK stations received USD 100 thousand.

According to the Law "On Amendments to Certain Laws of Ukraine on Improving the Conditions for Promoting Electricity Generation from Renewable Energy Sources" the tariff was reduced by $15 \%$ for industrial solar stations, which were commissioned from July 1, 2015 to December 31, 2019 with a capacity of more than $1 \mathrm{MW}$. For solar stations that were commissioned after 2019 , the reduction is $17.5 \%$. For individuals who build solar stations from 2020 to 2021 , the tariff is EUR 0.16. This tariff will be adjusted according to the EUR exchange rate every 3 months. Therefore, pricing in solar energy indicates the priority of artificial maneuverings of the green tariff depending on the totality of solar stations. In addition, the lobbying mechanism of Ukrainian oligarchs allowed to tie the green tariff to exchange rate fluctuations, as well as guarantee the priority of large solar stations for 10 years, while household stations will be forced to meet the personal needs of these households in electricity, and excess electricity will be submitted to the general power supply network for free.

Thus, the pricing of solar electricity has a rather complex mechanism and is determined by the influence of numerical factors. However, it is based on the cost mechanism. The most important cost element is the value of the land and this value varies depending on the geographical location and especially on the state regulation of land relations. The second factor is the cost of solar cell elements. This cost depends on the production technology and has a clear tendency to 
decrease due to the increase in mass industrial production and innovative solutions. The third factor is the financial and tax elements of state regulation of the development and promotion of solar power plants. The fourth factor is investment in the development of structural branches of solar generation.

In this sense, the mathematical dependence on these factors is a differential equation with separate variables $(x, y)=f_{1}(x) f_{2}(y) f_{3}(z) f_{4}(i)$ :

$$
\frac{d y}{d x}=f_{1}(x) f_{2}(y) f_{3}(z) f_{4}(i)
$$

Mathematically, these variables in the country's economy are not always zero.

$$
(x, y)=\left\{\begin{array}{l}
f_{1}(x) ; \text { has a tendency to increase } \\
f_{2}(y) ; \text { tends to decrease } \\
f_{3}(z) ; \text { depends by government policy } \\
f_{4}(i) ; \text { determined by government policy }
\end{array}\right.
$$

In both parts of the obtained equation there are differentials of the functions of the argument $x$.

From the equality of the differentials of these functions it follows that the functions themselves differ from each other by some constant, and its value depends on the level of state regulation of solar energy.

\section{Conclusions}

Direct sources of inexhaustible solar energy began to be used industrially only during the energy crisis of the 1970s, which indicates the need to urgently find alternative cheap energy sources. Power plants began to be formed and large-scale national programs for the development of alternative energy were developed and implemented, among which the most successful were "Sunlight" (Japan, since 1976), "Solar Roofs" (USA) and "Golden Sun" (China, since 2009).

The solar boom in electricity generation began in the 21st century with the implementation of the UN concept of sustainable development and the implementation of the Paris Agreement within the framework of the UN Framework Convention on Climate Change. This provided 3\% of the annual growth of solar energy in the world. However, quarantine measures and limited leisure production with the introduction of anti-pandemic measures led to a drop in solar energy growth by one percent point.

All long-term forecasts point to the future growth in the introduction of solar stations. At the same time, scientists prove the efficiency of these stations in a complex-regional combination 
into a single energy system, which will use the principle of full lighting for 24 hours a day (due to changes in time zones). However, such theoretical views on this period in practice are not implemented due to the small share of solar generation and the action of various economic and political sanctions.

A special tool in the intensive increase in the production of solar electricity is the tariff formation for the sale of solar energy. Unequivocally, the introduction of the green tariff initiated a rapid increase in solar stations for both industrial and households. The tendency to reduce the value of the green tariff is a manifestation of the economic principle and economic feasibility and reduces distortions in the sale of electricity generated by various power plants. However, such reductions still remain a lever for lobbying big business in the energy sector of the national economy in order to obtain a guaranteed return on investment in solar power plants. At the same time, the problem of stimulating the introduction of solar stations for the needs of households remains a remark in the state regulation. There is no theoretically substantiated mechanism of such incentives for mass use of solar panels for households.

The problem of utilization of the equipment of solar stations after the fulfilled term gets further aggravation. At present, such recycling is the primary feature - dismantled element of non-ferrous metals (rough processing). Solar panels themselves are recycled by only $10 \%$, and most solar panels are sent for use to power plants in third countries or exported as waste to the same countries. The European Union (EU) was the first to introduce recycling standards by Directive 2012/19/EU and these requirements are included in the national legislation of the EU countries. Due to such state regulation, the requirements that prevent the protection of the environment and the implementation of operations for deep processing of solar panels have been fulfilled. Only since 2018, the technology of deep processing of panels using the technology of zero runoff of liquid waste has been introduced.

The competitiveness of solar energy is relatively low. However, from the standpoint of replacing energy fuel at a cost of USD 10 per $0.116 \mathrm{Wh}$ of solar energy saves 10-20 million tons of conventional fuel. Industrial production of solar electricity at modern solar power plants forms a price at the level of USD 250-450 for $1 \mathrm{MWh}$.

Today's solar generation is still quite vulnerable to climatic factors. This is very critical in the event of sudden cataclysms, especially in winter. Therefore, the development of solar energy as an independent energy system with modern technologies is not a sufficient condition for efficient energy supply.

\section{References}

ALAWAJI, S.H. 2001. Evaluation of solar energy research and its applications in Saudi Arabia - 20 years of experience. Renew. Sustain. Energy Rev. 5, pp. 59-77, DOI: 10.1016/S1364-0321(00)00006-X.

Alster et al. 2021 - Alster, G., Brown, S. and Broadbent, H. 2021. Monthly European insights - ember.

Ember-climate.org. [Online] https://www.ember-climate.org [Accessed: 2021-02-05].

BNEF 2021. BNEF Pioneers 2021. [Online] https://about.bnef.com [Accessed: 2021-05-11]. 
Ciula et al. 2019 - Ciula, J., Gaska, K., Siedlarz, D. and Koval, V. 2019. Management of sewage sludge energy use with the application of bi-functional bioreactor as an element of pure production in industry. E3S Web Conf. 123, 1016, DOI: 10.1051/e3sconf/201912301016.

David et al. 2020 - David, T.M., Silva Rocha Rizol, P.M., Guerreiro Machado, M.A. and Buccieri, G.P. 2020. Future research tendencies for solar energy management using a bibliometric analysis, 2000-2019. Heliyon 6, e04452, DOI: 10.1016/j.heliyon.2020.e04452.

ELECTRICITY 2021. ELECTRICITY. [Online] https://www.eia.gov [Accessed: 2021-05-11].

EU Market Outlook... 2020. EU Market Outlook for Solar Power, 2020-2024. [Online] https://www.solarpowereurope.org/category/reports [Accessed: 2021-05-11].

European... 2020. European Pattern Recognition Project. [Online] https://europeanpatternrecognition.eu [Accessed: 2021-05-11].

Gielen et al. 2019 - Gielen, D., Boshell, F., Saygin, D., Bazilian, M.D., Wagner, N. and Gorini, R. 2019. The role of renewable energy in the global energy transformation. Energy Strateg. Rev. 24, 38-50, DOI: 10.1016/j.esr.2019.01.006.

Haddad et al. 2019 - Haddad, M., Nicod, J., Mainassara, Y.B., Rabehasaina, L., Al Masry, Z. and PÉRA, M. 2019. Wind and solar forecasting for renewable energy system using SARIMA-based model. [In:] International Conference on Time Series and Forecasting, Gran Canaria.

HÁK et al. 2019 - HÁk, T., JanoušKová, S. and Moldan, B. 2016. Sustainable Development Goals: A need for relevant indicators. Ecol. Indic. 60, pp. 565-573, DOI: 10.1016/j.ecolind.2015.08.003.

HAYES, J. 2012. A study on the effects of solar power. Fayetteville: University of Arkansas.

Household... 2021. Household electricity prices worldwide in September 2020, by select country. [Online] https://www.statista.com [Accessed: 2021-05-11].

Hutsaliuk et al. 2020 - Hutsaliuk, O., Koval, V., Tsimoshynska, O., Koval, M. and Skyba, H. 2020. Risk Management of Forming Enterprises Integration Corporate Strategy. TEM J. 9, pp. 1514-1523, DOI: 10.18421/TEM94-26.

IRENA 2020a. Renewable Capacity Statistics 2020. [Online] https://www.irena.org/-/media/Files/IRENA/ Agency/Publication/2020/Jun/IRENA_Power_Generation_Costs_2019.pdf [Accessed: 2021-05-11].

IRENA 2020b. Renewable Power Generation Costs in 2019. [Online] https://irena.org/publications/2020/ Mar/Renewable-Capacity-Statistics-2020 [Accessed: 2021-05-11].

Kaczmarzewski et al. 2019 - Kaczmarzewski, S., Olczak, P. and Halbina, A. 2019. Issues of photovoltaic installation size choice for a hard coal mine. E3S Web of Conferences, DOI: 10.1051/e3sconf $/ 201912301014$.

Kaliappan et al. 2019 - Kaliappan, K., Sankar, M., Karthikeyan, B., Vineeth, B. and Raju, V.C. 2019. Analysis of solar energy technology in leading countries. International Journal of Power Electronics and Drive Systems 10(4), 1995.

Koval et al. 2019a - Koval, V., Sribna, Y. and Gaska, K. 2019a. Energy Cooperation Ukraine-Poland to Strengthen Energy Security. E3S Web Conf. 132, 1009, DOI: 10.1051/e3sconf/201913201009.

Koval et al. 2019b - Koval, V., SRibna, Y., Mykolenko, O. and Vdovenko, N. 2019b. Environmenta concept of energy security solutions of local communities based on energy logistics. $19^{\text {th }}$ International Multidisciplinary Scientific GeoConference SGEM 2019, International Multidisciplinary Scientific GeoConference-SGEM. STEF92 Technology, 51 Alexander Malinov blvd, Sofia, 1712, Bulgaria, pp. 283-290, DOI: 10.5593/sgem2019/5.3/S21.036.

Kumar, M. 2020. Social, economic, and environmental impacts of renewable energy resources. [In:] Okedu, K.E. (ed.), Wind Solar Hybrid Renewable Energy System. IntechOpen, DOI: 10.8772/interopen 77440 .

LEWIS, N.S. 2016. Research opportunities to advance solar energy utilization. Science 351(6271), pp. 62-71 , DOI: $10.1126 /$ science.aad1920. 
Majchrzak et al. 2021 - Majchrzak, K., Olczak, P., Matuszewska, D. and Wdowin, M. 2021. Economic and environmental assessment of the use of electric cars in Poland. Energy Policy Journal 24, pp. $153-168$.

Mikhno et al. 2021 - Mikhno, I., Koval, V., Shvets, G., Garmatiuk, O. and Tamosiuniene, R. 2021. Green Economy in Sustainable Development and Improvement of Resource Efficiency. Cent. Eur. Bus. Rev. 10, pp. 99-113, DOI: 10.18267/j.cebr.252.

Mirowski, T. and Sornek, K. 2015. Potential of prosumer power engineering in Poland by example of micro PV installation in private construction. Energy Policy Journal 18, pp. 73-84.

Mulatu, M.A. 2017. Energy cooperation in communication of energy harvesting tags. AEU-Int. J. Electron. Commun. 71, pp. 145-151, DOI: 10.1016/j.aeue.2016.10.016.

NaJMabadi, S. 2021. Texans blindsided by massive electric bills await details of Gov. Greg Abbott's promised relief. Texas Trib. [Online] https://www.sanmarcosrecord.com [Accessed: 2021-05$-11]$.

Онта, H. 2020. The Analysis of Japan's Energy and Climate Policy from the Aspect of Anticipatory Governance. Energies 13(19), DOI: 10.3390/en13195153.

Olczak et al. 2021 - OlczaK, P., Olek, M., Matuszewska, D., Dyczko, A. and Mania, T. 2021. Monofacial and Bifacial Micro PV Installation as Element of Energy Transition - The Case of Poland. Energies 14(2), DOI: 10.3390/en14020499.

Owusu, P.A. and Asumadu-SARKodiE, S. 2016. A review of renewable energy sources, sustainability issues and climate change mitigation. Cogent Eng. 3, 1167990, DOI: 10.1080/23311916.2016.1167990.

Pattanaik et al. 2020 - Pattanaik, D., Mishra, S., Khuntia, G.P., Dash, R. and Swain, S.C. 2020. An innovative learning approach for solar power forecasting using genetic algorithm and artificial neural network. Open Eng. 10, pp. 630-641, DOI: 10.1515/eng-2020-0073.

RAVIRAJAN, P. 2017. Solar energy for sustainable development in developing countries. Ceylon Journal of Science 46(2), DOI: 10.4038/cjs.v46i2.7424.

Renewable energy 2021. [Online] https://ec.europa.eu/energy/topics/renewable-energy_enWWW [Accessed: 2021-05-11].

Shahsavari, A. and Akbari, M. 2018. Potential of solar energy in developing countries for reducing energy-related emissions. Renewable and Sustainable Energy Reviews 90, pp. 275-291, DOI: 10.1016/j. rser.2018.03.065

Solar... 2021. Solar Industry Research Data. [Online] https://www.seia.org [Accessed: 2021-02-21].

Spillias et al. 2020 - Spillias, S., Kareiva, P., Ruckelshaus, M. and McDonald-Madden, E. 2020. Renewable energy targets may undermine their sustainability. Nat. Clim. Chang. 10, pp. 974-976. DOI: $10.1038 / \mathrm{s} 41558-020-00939-\mathrm{x}$.

Sustainability... 2019. Sustainability Leadership Standard for Photovoltaic Modules and Photovoltaic Inverters, 2019. Michigan.

The IPCC's reports 2021. Intergov. Panel Clim. Chang. [Online] https://www.ipcc.ch/about/preparingreports [Accessed: 2021-02-21].

Total installed... 2020. Total installed power capacity by fuel and technology 2019-2025, main case. Int Energy Agency. [Online] https://www.iea.org/ [Accessed: 2021-02-21].

Transforming... 2015. Transforming Our World: An Agenda for Sustainable Development until 2030. United Nation. [Online] https://sustainabledevelopment.un.org [Accessed: 2021-02-21].

Tsimoshynska et al. 2021 - Tsimoshynska, O., Koval, M., Kryshtal, H., Filipishyna, L., Arsawan, W.E. and KovaL, V. 2021. Investing in road construction infrastructure projects under public-private partnership in the form of concession. Nauk. Visnyk Natsionalnoho Hirnychoho Universytetu, pp. 184-192, DOI: $10.33271 /$ nvngu/2021-2/184.

Utility-Scale 2021. First Sol. [Online] https://www.firstsolar.com [Accessed: 2021-02-21]. 
Verkhovna Rada of Ukraine 2020. About modification of some laws of Ukraine concerning improvement. Kyiv.

Viebahn et al. 2011 - Viebahn, P., Lechon, Y. and Trieb, F. 2011. The potential role of concentrated solar power (CSP) in Africa and Europe - A dynamic assessment of technology development, cost development and life cycle inventories until 2050. Energy Policy 39, pp. 4420-4430, 4421.

Wan et al. 2015 - Wan, C., ZhaO, J., Song, Y., Xu, Z., Lin, J. and Hu, Z. 2015. Photovoltaic and solar power forecasting for smart grid energy management. CSEE J. Power Energy Syst. 1, pp. 38-46, DOI: 10.17775/CSEEJPES.2015.00046.

WANG et al. 2017 - WANG, Y., LuO, G. and KANG, H. 2017. Successes and Failures of China's Golden-Sun Program, in: Proceedings of the $20176^{\text {th }}$ International Conference on Energy, Environment and Sustainable Development (ICEESD 2017). Atlantis Press, pp. 585-606, DOI: 10.2991/iceesd-17.2017.109.

Wang et al. 2019 - Wang, Q., Chang, P., BAI, R., LiU, W., DAI, J. and Tang, Y. 2019. Mitigation strategy for duck curve in high photovoltaic penetration power system using concentrating solar power station. Energies 12(18), DOI: 10.3390/en12183521.

Weckend et al. 2016 - Weckend, S., Wade, A. and Garvin, H. 2016. End-of-life management: Solar Photovoltaic Panels. International Renewable Energy Agency.

WróBlewski et al. 2021 - WróBlewsKi, P., DrożDż, W., LEWICKI, W. and MiĄzeK, P. 2021. Methodology for Assessing the Impact of Aperiodic Phenomena on the Energy Balance of Propulsion Engines in Vehicle Electromobility Systems for Given Areas. Energies 14(8), DOI: 10.3390/en14082314.

Żelazna et al. 2020 - Żelazna, A., GoŁęBiowska, J., ZDYB, A. and PAwŁowski, A. 2020. A hybrid vs. on-grid photovoltaic system: Multicriteria analysis of environmental, economic, and technical aspects in life cycle perspective. Energies 13(15), DOI: 10.3390/en13153978.

Yevheniia Sribna, Viktor Koval, Piotr OlczaK, Dmytro Bizonych, Dominika MatuszewsKa, Oleksandr SHTYRov

\section{Prognozowanie wytwarzania energii słonecznej w systemach energetycznych w celu przyspieszenia implementacji zrównoważonego rozwoju gospodarczego}

\section{Streszczenie}

Przeprowadzono analizę rozwoju energetyki słonecznej w zakresie wzrostu produkcji energii słonecznej na świecie (wzrost w ostatnim roku o ponad 15\%). Dane z roku 2020 pokazują, że jest ponad 37 krajów w których łączna moc zainstalowana w fotowoltaice przekracza $1 \mathrm{GW}$, a udział energii słonecznej w całkowitej światowej produkcji energii elektrycznej wyniósł 8,15\%. W kontekście regionalnym największa produkcja energii elektrycznej ze źródeł energii słonecznej występuje w Azji (głównie Chiny i Indie) oraz w Ameryce Północnej (USA). W pracy oceniono główne czynniki rozwoju energetyki słonecznej z punktu widzenia przyjazności dla środowiska i stabilności dostaw energii elektrycznej. Rozważany jest także problem wykorzystania wyposażenia stacji fotowoltaicznych w UE i USA. Z uwzględnieniem IPCC, 
IEA, Solar Power Europe analizowany jest także aspekt prognozowania rozwoju energetyki słonecznej na świecie. W pracy wykazano, że głównym czynnikiem oceny efektywności ekonomicznej produkcji energii słonecznej jest zróżnicowanie regionalne ze względu na warunki naturalne i klimatyczne (natężenie promieniowania słonecznego). Ponadto wykorzystywanie energii słonecznej ma charakter pomocniczy w pracy nowoczesnych sieci elektrycznych, o ile sprawność ogniw fotowoltaicznych wzrośnie o co najmniej $60-65 \%$ (w stosunku do stanu obecnego).

Koszty krańcowe wykorzystania energii słonecznej są minimalne w krajach, w których udzielane jest aktywne wsparcie państwa. Natomiast konkurencyjność energii słonecznej jest stosunkowo niska. Ocenia się że zastępując paliwa energetyczne o koszcie 10 USD za 1 Gcal, dzięki energii słonecznej oszczędza się 10-20 mln ton paliwa konwencjonalnego rocznie. Przemysłowa produkcja energii słonecznej w nowoczesnych elektrowniach słonecznych kształtuje się na poziomie 250-450 USD za $1 \mathrm{MWh}$.

SŁOWA KLUCZOWE: energia słoneczna, produkcja i zużycie energii elektrycznej, taryfa „zielona”, utylizacja paneli słonecznych 
